\title{
LETTERS TO AFRICA
}

Letters to the Editor should be signed and give the full address and position of the writer. The Editor reserves the right to shorten letters or to decline them.

\section{From Dr. Robert Wade}

Sir, One of the problems which economic anthropology faces is that of developing a way to incorpotate both economic variables (like income alternatives) and social structural variables (like inheritance) in the same logical framework. Until this is done, we are unlikely to progress much beyond the view, still prevalent in anthropology, that social structural conditions are somehow primary in accounting for social phenomena and economic conditions somehow secondary. In this note I shall show how one attempt to demonstrate the validity of this view fails, because it assumes the conclusion it seeks to demonstrate; and I shall also show, in a very preliminary way, how the integration of economic and social structural variables can in this case be made.

I shall examine Goody's explanation of why the LoWiili and the LoDagaba, neighbouring communities in northern Ghana, have different-sized farming groups. Though written fifteen years ago it has not to my knowledge been subsequently questioned. Yet it concludes with a quite unambiguous statement of the priority of inheritance over factors pertaining to economic organization and scarcity. 'In general, .... the difference in the size of farming groups in the two communities is to be related to difference in systems of property relations [i.e. inheritance patterns] rather than in the productive systems themselves.' (1958: 71) I shall argue that he reaches this conclusion by including only the costs which bear on work group choices; had he considered both costs and benefits he would have brought features of the productive system into his analysis as essential elements of the explanation.

The LoWiili have relatively large farming groups, frequently made up of a man and his adult married sons, or two or mote married brothers; the LoDagaba have smaller, less extended units. In absolute terms, the LoWiili farming groups average 2.5 men and $I I \cdot I$ persons (men, women, children) while the LoDagaba groups average $x .5$ men and 7.0 persons. (1958:65) In other words, the process of fission in the domestic group takes place earlier among the LoDagaba than among the LoWiili. Cultural traditions and crops are the same in both communities, cultivation practices are similar, but methods of property inheritance differ. The LoWiili are patrilineal: property is divided among a man's children at his death. The LoDagaba are both patri- and matrilineal: certain kinds of property - mainly immovables such as land and buildings-are passed on to a man's sons, while other property-mainly livestock and money - goes to his sister's sons. LoDagaba sons, therefore, have an incentive to break off from their father's unit once they are capable of managing one on their own. If they remain with their father they will help him to fill his grain store-output is controlled by the father-and will thus help him to buy more livestock. When he dies this wealth passes not to his sons but to the sons of his sister. It is, therefore, to the sons' advantage to establish their own grain stores and livestock herds as soon as possible. LoWiili sons, on the other hand, have no such incentive for they stand to receive all their father's property. Thus, LoWiili farming groups are larger and more extended.

There is no doubt that the difference in inheritance practices has a large impact on the size of the farming group, but it is also clear that features of the productive system are important. Essentially Goody's argument is that a LoDagaba son who remains with his father faces a cost, the future expected loss of assets (money and livestock) when his father dies. What about the benefits? This is the question Goody does not ask, and it cannot be answered without considering features of the ecology and the agricultural system. From Goody's material it appears that (with the exception of the youngest son) there is little advantage to be gained by remaining with the father. Land is freely available, so that getting access to the main productive resource is not problematic. Communal labour is available in the form of 'farming parties', so that a son can get essential help at times of peak labour requirements and can thereby operate a farm with a relatively small regular labour force. Moreover, sons have access to income through migration to towns, which means that alternative means of livelihood are open to them beyond agriculture in the local community. For the LoWiili the incentives are very different. Land is scarce, communal labour practices hardly operate, farm work includes labour intensive activities such as cattleminding and manure spreading, and migration opportunities are restricted. In these conditions one expects that more is to be gained by remaining in the father's household and sharing its produce; and the patrilineal inheritance system ensures that there is no expected loss of capital on the death of the father.

Goody reaches his conclusion by concentrating only on the costs of alternative actions. Analysis of benefits brings in features of the productive system such as land scarcity, availability of alternative income sources, availability of labour supplies beyond the domestic group. If land was (or became) scarce among the LoDagaba, if no seasonal off-farm 
employment was available, if no means of recruiting communal labour existed, the size of the farming group would be larger than it is, despite the matrilineal inheritance pattern.

The central point is that the size of the household or farming unit, the frequency of fission and the stage in the developmental cycle when it occurs, depends on the costs and benefits from remaining or moving out. 'The lesson to be learnt from Goody's study is that inheritance patterns may have a sig-

1 A puzzle suggested by Goody's material could be noted here. If the figures for farm group size and yields per acre are at all accurate, the LoDagaba have production levels per person 70-100 per cent higher than the LoWiili. (Multiply land/person (p. 7I) by yield/acre (p. $\sigma_{3}$ ) to get yield/person for both communities.) One wonders what differences in social organization correlate with a difference of this order in production; and, given that the communities are nificant effect on domestic group size and extension through their impact on the expected future costs and benefits of alternative residence and work decisions; but they cannot be given the independent causal role Goody attributes to them. I

Yours faithfully,

ROBERT WADE

Institute of Development Studies

University of Sussex

neighbouring, one wonders what mechanisms prevent a diminution of the production differences. In this light, it is perhaps surprising to learn that seasonal migration to the towns, where returns to labour are presumably equal to or greater than returns to labour in local agriculture, is considerably higher among the LoDagaba than among the apparently much poorer LoWiili. Other things being equal, this is not what one would expect.

\section{REFERENCE CITED}

Goony, J. 1958. 'The Fission of Domestic Groups among the LoDagaba.' In Goody, J. (ed.), The Developmental Cycle in Domestic Groups. Cambridge: University Press.

\section{From Dr. Polly Hill}

$\mathrm{Sir}$, In his recent article "Changing Family Structures among the Rural Hausa'I A. D. Goddard argues that his findings in the Sokoto close-settled zone regarding the institution of paternal gandu (under which sons continue to work on their father's farms after marriage) are of general application to Nigerian Hausaland. In this brief Note I am concerned to dispute this conclusion, as well as some of the presumptions on which it is based.

However, before turning to the Hausa case, I wish to draw attention to the great dearth of information, for West Africa generally, on the process by which sons establish themselves after marriage as independent farmers, free of paternal control. Far more significant than the matter of residence after marriage, is that of rights over farmland. While the process of parting from the father is immediate in many societies and circumstances, in others it is long drawn out, or attainable only on the father's death. Daryll Forde, in Yakö Studies, ${ }^{2}$ provides one of the clearest examples of a process which starts on martiage and is completed a few years later. But one searches most sources in vain for similar material concerning this important aspect of land tenure.

Presumably Goddard had had insufficient time in which to consult my Rural Hausa ${ }^{3}$ for otherwise he would not have asserted (p. 207) that there is a surprising lack of recent literature on gandu. 4 However,

I Africa, July I 973.

2 Forde, 1964: I8.

3 Which was published in March 1972 and is included in his list of references.

4 See Hill, 1972, Chapter III, 'Fathers and sons in his Table V he presents some misleading statistics, indirectly derived from one of my superseded publications, relating to what he calls the 'incidence' of gandu. Incidence figures should relate the actual to the possible: in this case they should tell us the proportion of married men with living fathers who ate in gandu, not (as in Table V) the proportion of all married men. The fact that only 46 per cent of married men are shown in that table as having been in gandu in Batagarawa ${ }^{5}$ is mainly due to the high incidence of fatherless married men: in fact the real incidence of paternal gandu was very high, for only Io out of 69 married sons had left gandu, and they were the sons of only six fathers.

In my more recent work in very densely populated Dorayi, in the Kano close-settled zone, ${ }^{6}$ I found that paternal gandu was even stronger than in Batagarawa, in terms both of incidence and the nature of the economic and other links between father and married son; one important and obvious explanation for this was the extreme searcity of farmland, which prevented fathers from giving land to their sons, or sons from acquiring land for themselves. To such a degree were sons subordinate to their fathers, that (quite unusually) those who commuted to Kano city for wage-earning work (as distinct from 'own account' occupations, such as trading) were spoken of as being in gandu and were expected to hand over part of their earnings to their fathers.

in gandu'.

5 The Katsina village on which Hill, $x 972$, is based.

${ }^{6}$ See Hill, $x 974$. 
Of course, paternal gandu is usually much more than an economic relationship between father and son. Thus the willingness of relatively rich sons to remain in gandu in Batagarawa was partly explicable in terms of such factors as family pride, obligations, and sentiment. So strong are these 'sentiments' in Dorayi that few sons with living fathers break their obligations by migrating ${ }^{\mathrm{I}}$ - though there is a fairly high incidence of migration following the father's death; and so much shame attaches to such migration when it does occur that in many cases sons vanish orernight, never to be seen again. ${ }^{2}$

On the basis of my own and others' 3 research, it is my working hypothesis that except in extraordinary circumstances - such as may prevail in the Sokoto close-settled zone, if only because of the exceptionally high tate of dry-season migration-the important institution of paternal gandu in Nigerian Hausaland is, and will long remain, very strong, in the sense that married sons will mainly work on their father's farmland. In any case, if I read Table III aright, in two of the three Sokoto localities, over 70 per cent of resident married sons ${ }^{4}$ were in gandu-not a notably low figure. Nor does the fact that Sokoto sons are often ${ }^{5}$ notional owners of portions of communally-farmed gandu land (p. 214) affect the gandu principle, if (as I presume) they may not sell these portions.

Goddard insists that in Sokoto farmers have 'increasingly turned' to non-farming occupations and that the same is true in densely populated Kano Emirate (p. 216); he also argues that this trend can be expected to 'spread' as population increases. He presumes that the diminishing importance of gandu is associated with these trends. Perhaps this is true in Sokoto, but in Dorayi (in Kano Emirate), where gandu is so strong, I am struck (as I have been else-

1 Of a total of some 227 married sons, only about Io per cent had migrated.

2 See Hill, $x 974$.

3 See Hill, I972, for references.

4 The heading of Table III is both obscure and ungrammatical. Are conjugal familes (iyalai) headed by fathers of married ons (as well as by married sons themselves) included? How can iyalai (as such) be in gandu? where), ${ }^{6}$ by the declining importance of rurally based craftwork and long-distance trade.

Goddard rightly attaches much importance to gandu as a mutual security system, though he is wrong in stating (pp. 216-17) that 'most [Hausa] farmers live near a subsistence level', for pronounced economic inequality is an inherent feature of rural life. ${ }^{7}$ However, there is no necessity to postulate a high incidence of severe poverty in support of my general working hypothesis regarding the strength of paternal gandu, which derives sufficient support from the following types of consideration, among many others.

(I) In a tegion where climatic conditions are so harsh, individual farmers (whether fathers or sons) stand exposed to the elements and benefit greatly from farming as a corporate group. (2) (a) Increased Muslim wife seclusion (which is probably nowadays nearly universal in most ateas of rural Nigerian Hausaland $)^{8}$ prevents the wives of even the most impoverished farmers from farming; (b) rapidly rising matriage and child-bitth expenses which sons can seldom meet for themselves; (c) the rapidly rising price of land; $(d)$ the decline of rural craftwork and long-distance trade-all these are changes which tend to strengthen gandu. (3) There is not necessarily any conflict between a son's desire for increased economic independence and his gandu obligations which are very flexible. 9 (4) The gandu institution enables elderly fathers to hand over their responsibilities to their sons in a gradual and orderly way. (5) Hausa men are usually prepared to work in a subordinate capacity under their fathers, but not under their elder brothers-hence the weakness of fraternal gandu.

Yours faithfully,

Polly Hill

5 The frequency of such arrangements is unclear, as fraternal gandaye, which are often very loosely organized, are not separately distinguished.

6 See Hill, 1972.

7 See Hill, 1972. (More recent work has confirmed these findings.)

8 But not in the Niger Republic-see Goddatd's footnote 3 in this connection.

- See Hill, 1972.

\section{REFERENCES}

Forde, Darylz. I964. Yakö Studies. Oxford: International African Institute.

Hrul, Polly. 1972. Rural Hausa: A Village and a Setting. Cambridge.

1974. 'Big Houses in Kano Emirate', Africa, xliv. 2, Apr.

\section{From Mr. Hector Blackhurst}

Sir, Three points arise from C. R. Hallpike's letter (Africa, April 1974) concerning my review of The Konso of Ethiopia to which I would like to reply.

First, Hallpike has a genuine grievance when he complains that I failed to mention his discussion of
Konso generation grades. This was an oversight on my part for which I owe him and interested readers an apology. However, it is disingenuous of Hallpike to say in his letter that his monograph was concerned with 'in particular the working of the generation grading systems'. I can find no evidence in the book 
to show that it was written with special reference to the grades. The chapter on the grading system does not provide the theme of the book; rather it illustrates the theme as presented in a section of the Introduction entitled 'The Aims of this Monograph' where, incidentally, no mention is made of generation grades.

The truth of the matter is that the generation grades are no more central to the monograph than the other topics Hallpike discusses. What is central is his attempt to demonstrate the role of Konso values in relation to their institutions and rituals, as he himself reiterates in his letter. I naturally, therefore, directed my review to what I, and I thought the author, considered to be the central thesis of the book.

Secondly, Hallpike attempts to rebut my statement that he 'studied the values without the society' by referring to his discussion of the status of craftsmen and the relations between warriors and elders. However, the general statements about the relationships between formal statuses contained in these sections of the book are no substitute for more detailed information about "people on the ground, interacting, exchanging goods and competing for women and other desirables' (The Konso, p. I6) with which Hallpike dispenses.

Thirdly, it is not unreasoning ideological prejudice which led me to deplore the absence of such information. Within the space available I gave my reasons, hence the specific example of Hallpike's conclusions concerning the Konso pattern of settlement. This statement seems to me to typify the nature of argument which must follow when, in the absence of other information, an overemphasis is given to a people's own view of their society and its uniqueness. That this has happened in the present instance is apparent from Hallpike's use of such phrases as 'cultural obsession' and 'the special personality of each culture'.

Whatever these phrases mean, if indeed they mean anything, they come dangerously close to cultural solipsism. This may be a useful descriptive device but it is a denial of the possibility of a general study of society, including values.

These are important issues. Nothing in Hallpike's book or his letter suggests to me that he realizes the implications of his own position, except perhaps its weakness. How else am I to explain the torrent of unjustified invective in his letter, other than as an attempt to obscure the real issues by casting aspersions on the professional competence and integrity of your reviewer?

Yours faithfully,

HeCtor BLACKHURST

\section{Journal of Southern African Studies}

The Oxford University Press have published a new periodical (first issue October 1974): Journal of Southern African Studies. It is concerned with all Africa south of Katanga and its content is mainly in the field of social sciences, its approach being both inter-disciplinary and objective. It is to be published twice yearly, in October and April. The annual subscription is 64.00 (\$13.00). The Editors are: Anthony Atmore, Richard Hodder-Williams, and J. E. Spence. 